\author{
Revista Minelor - Mining Revue \\ ISSN-L 1220-2053 / ISSN 2247-8590 \\ vol. 27, issue 4 / 2021, pp. 7-18
}

\title{
INVESTIGATIONS ON THE STABILITY OF THE RIGHT SLOPE IN THE AREA OF ANINA WASTEWATER TREATMENT PLANT
}

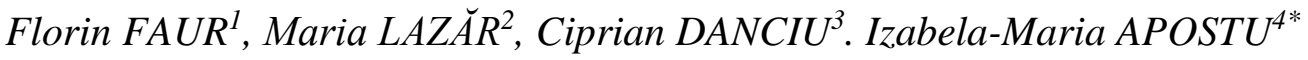 \\ ${ }^{1}$ University of Petrosani, Faculty of Mining, Department of Environmental Engineering and Geology, Petrosani, \\ Romania, florinfaur@upet.ro \\ ${ }^{2}$ University of Petrosani, Faculty of Mining, Department of Environmental Engineering and Geology, Petrosani, \\ Romania, marialazar@upet.ro \\ ${ }^{3}$ University of Petrosani, Faculty of Mining, Department of Mining Engineering, Surveying and Constructions, \\ Petrosani, Romania, cipriandanciu@upet.ro \\ ${ }^{4}$ University of Petrosani, Faculty of Mining, Department of Environmental Engineering and Geology, Petrosani, \\ Romania, izabelaapostu@upet.ro
}

DOI: $10.2478 / \operatorname{minrv-2021-0030~}$

Keywords: consequent slide, stability, polygonal surface, right slope

Abstract: Often, excavations of natural slopes are necessary in the site area for the construction of civil or industrial objectives. The execution of such works requires special attention, from the design phase, regarding the stability of the slope in the initial state, but also after excavation and identification, if necessary, of technical solutions to increase the stability reserve, thus ensuring the security during the execution of works but also of future constructions. Such a situation was encountered in the case of Anina Wastewater Treatment Plant (WWTP), when, in the absence of proper investigations of the slope to be excavated, there was a landslide that interrupted the site activities, and which, to some extent, jeopardized the objectives already built. In this context, at the level of 2015, slope stabilization works were designed and executed, works that proved to be insufficient. In 2021, it was necessary to conduct a new stability study in order to analyze the possibilities of continuing the construction of the treatment plant. This paper presents the results obtained during this study, as well as a series of conclusions and interpretations, regarding the technical condition of the slope in different hypotheses.

\section{Introduction}

The town of Anina is located in Anina Mountains, that represent the southern extension of Western Carpathians, in Romanian Banat, having the coordinates 45 2'30 "north latitude and 21 ${ }^{\circ} 53^{\prime} 20^{\prime \prime}$ east longitude, in Caraş-Severin county. The average altitude of the settlement is $+645 \mathrm{~m}$ and the minimum is $+556 \mathrm{~m}$ and is located near the railway station [1] (Figure 1).

The town of Anina is located about $32 \mathrm{~km}$, on DN 58, from Reşita Municipality, the residence and administrative center of the county, at $33 \mathrm{~km}$, on DN 57B, from Oraviţa and at $34 \mathrm{~km}$, on DN 57B, from Bozovici towns.

Anina WWTP site is approx. $1.2 \mathrm{~km}$, on a NNE direction from Anina town, on the right bank of Gârliste River, inside Semenic Cheile Carașului National Park (Figure 1).

The main objective of this study was to investigate the technical condition (stability) of the right slope in WWTP Anina area (Gârliștei valley), and as a secondary objective to establish some recommendations on the possibility of carrying out excavation works, allowing the location of 4 premises (A1, A2, A8 and A11 according to the construction plan of WWTP Anina [2]).

We specify the fact that the investigated area was affected by a landslide (Figure 2), in 2015, subsequently being designed and executed land stabilization works, the technical solution being represented by a fixing system with metal nets and anchors [3].

\footnotetext{
* Corresponding author: Apostu Izabela-Maria, Assist.prof.dr.eng., University of Petrosani, Petrosani, Romania, (University of Petrosani, University Street no. 20, izabelaapostu@upet.ro)
} 


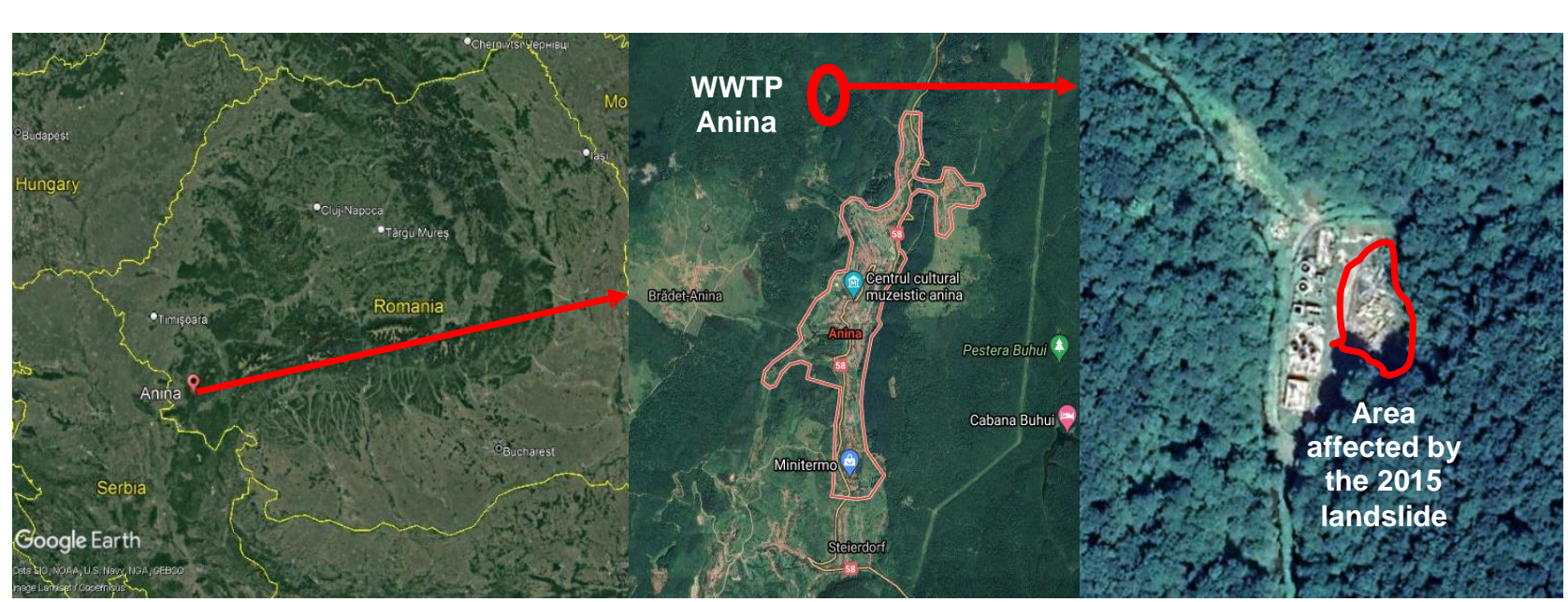

Figure 1. Location of the studied area

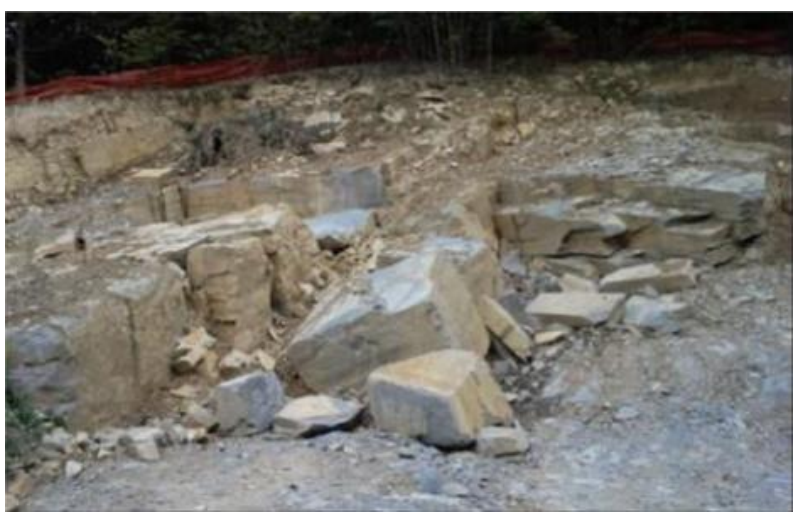

a

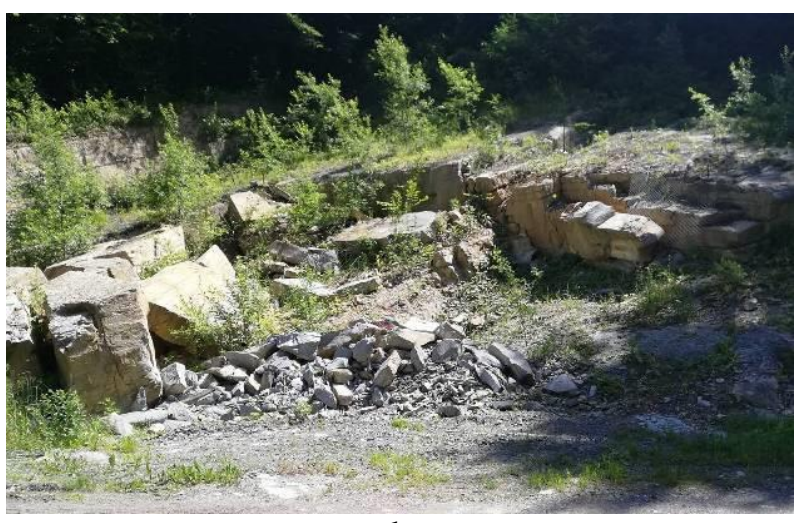

b

Figure 2. The landslide: a - in 2015 [3], immediately after the event; b - in 2021, relatively stabilized

Also in that period, a second variant of securing the slope was considered, namely with the help of retaining walls, in this sense being considered two technical solutions [4].

During the field investigations, it was found that part of the system consisting of metal nets and anchors gave way (Figure 3), requiring another solution to stabilize the slope.
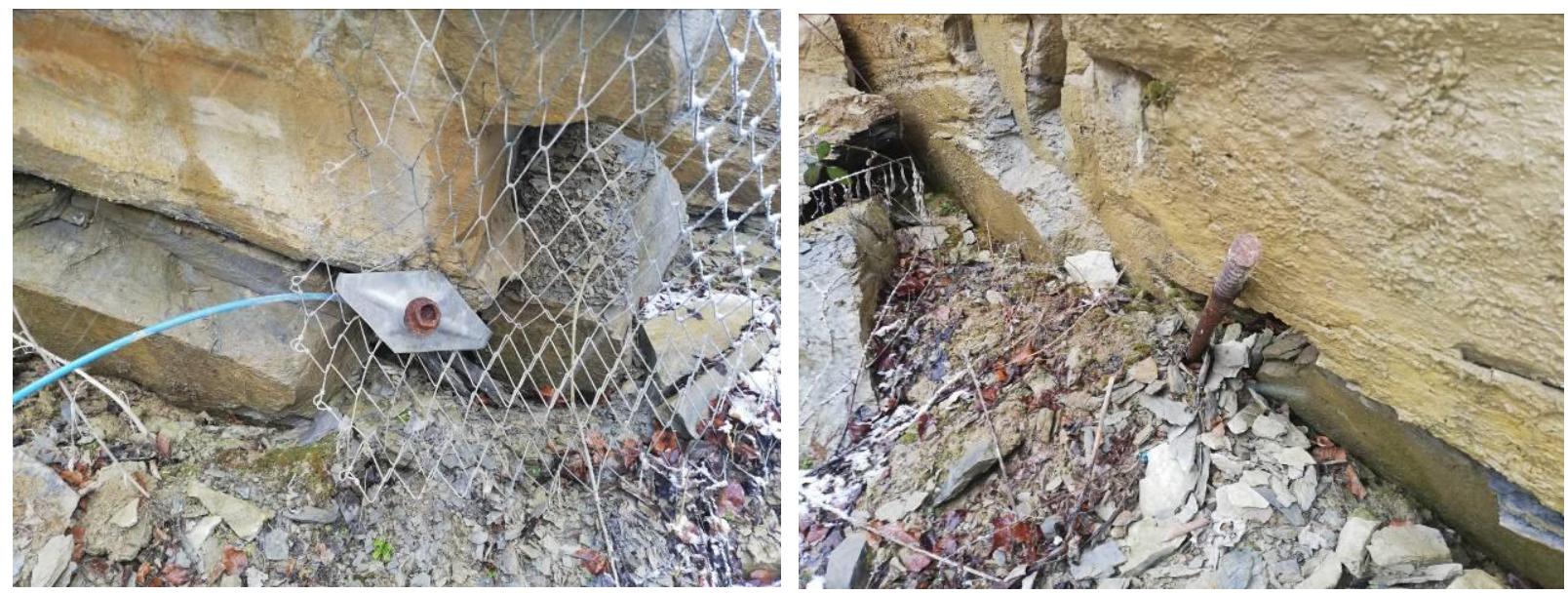

Figure 3. Damage to metal nets and anchors

We specify that the initial landslide occurred during the execution of excavation works at the base of the slope, allowing the location of the 4 enclosures mentioned, and was described as a consequent landslide (sliding surface inclining in the same direction as the stratification of the slope) on a slope of approx. $30^{\circ}$. The slide involved the movement of strongly altered sandstone blocks (especially physically: affected by massive cracks, developed both vertically and horizontally) and was favored by the presence of clays and water from precipitation [3] (Figure 4a). 
The sliding process involved the movement of large blocks of rock (20 - $40 \mathrm{t}$, and over $2 \mathrm{~m} \mathrm{high}$ ), had a surface development of approx. $15-20 \mathrm{~m}$ and manifested itself at a depth of approx. $7 \mathrm{~m}$ (Figure $4 \mathrm{~b}$ ). The body of the landslide was composed of an uneven mixture of massive blocks of altered and unaltered rocks with clay intercalations with moist content [1].

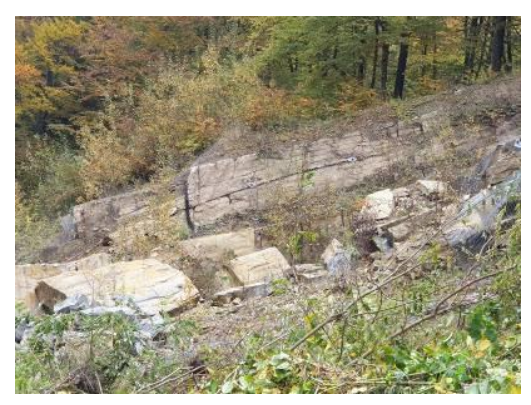

a

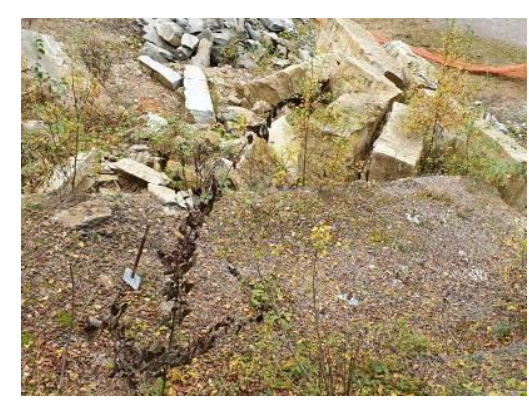

b

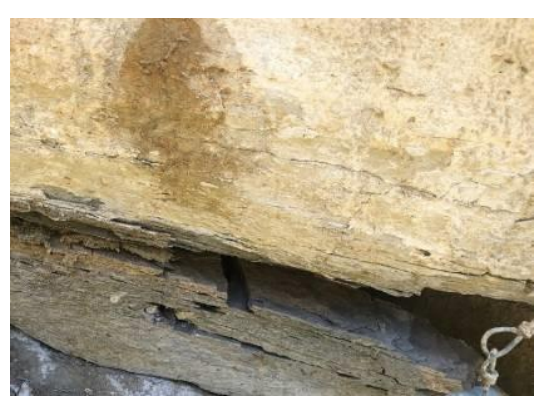

c

Figure 4. Stratigraphic aspects: a - the consequent inclination of the rock layers with that of the slope; $\mathrm{b}$ - the appearance of the rock blocks involved in the landslide from 2015; c - schistosity of slipped blocks

There is also the schistosity that characterizes the blocks involved in the landslide (Figure 4c) but also those left in place, and which in turn can have a significant influence in triggering a new landslide or in reactivating the one in 2015 . This schistosity can have implications and in choosing a future slope stabilization solution.

\section{Considerations regarding the geology of the massif, hydrology and climate}

\subsection{Geology}

Anina Mountains area is part of the mountainous and hilly unit developed on the alpine orogeny of Western Carpathians, Banat Mountains group, a subdivision of plateaus and limestone mountains within Reșita - Moldova Nouă syncline. This subdivision forms the middle region of Banat Mountains, in which the karst relief predominates. Anina Mountains have characteristic geomorphological features, as a consequence of their geological composition. The predominant rock is limestone arranged in synclines and anticlines with a NNVSSE direction, and the relief, adapted to the structure, consists of ridges and parallel valleys inscribed in the direction of the geological structure, and of extensive limestone plateaus "sifted" by sinkholes. To the east and north, sandstones and conglomerates appear in the Anina Mountains [1].

Due to the differentiated erosion, exerted on rocks with different hardness, as well as the tectonics, local depressions were born: Caraşova, Lişava, Ciudanoviţa, Anina etc.

The deposits on which the perimeter of the construction site is located are of Lower Permian, Lower Jurassic, Middle Jurassic and Holocene age [5]:

Lower Permian is represented at the base of the formation by black shale clays. Superior, it is progressively switched to red sandstones and clays with intercalations of conglomerates and red-purple archaic sandstones with green spots. On the edges of the sedimentation zone, the red horizon is arranged directly on Stephanian conglomerates or even on the crystalline.

Lower Jurassic begins with Lower Liassic, which presents in the basal part a coarse conglomerate, formed almost exclusively of quartz elements and crystalline schist, with siliceous cement. Over the basal conglomerates from Anina, there is an alternation of micaceous sandstones, clayey sandstones, coal shale, coal and refractory clays, with a thickness of approx. $250 \mathrm{~m}$. The Middle and the Upper Liassic are represented by a pelitic series, clayey-shale, a package called "bituminous shale horizon". Having a thickness of approx. 200 $\mathrm{m}$, this horizon consists predominantly of black schist that at the top gradually pass to the sandy gray clays where spherosiderite concretions are found.

Middle Jurassic is represented by Aalian-Callovian and is transgressive. Aalian and Bajocian are composed of gray or yellowish sandy marls with frequent Leioceras molds. Bathonian is generally marlycalcareous and frequently contains lamelibmanchiats. Callovian continues the marly-calcareous facies, being characterized by the presence of sandstone-calcareous ellipsoidal concretions.

Holocene is represented by an alternation of rolled gravels, sands and meadow dust. These are also common on the banks of various valleys. 
Analyzing the available documentation, we found that the three geotechnical studies conducted in May 2011, May 2015 and October 2015 identify differently the type of rocks that make up the massif:

- the study from May 2011 - conglomerates [5];

- the study from May 2015 - strongly altered sandstones [4];

- the study from October 2015 - limestone marls (with the aspect of weak sandstones) [1].

For this reason, on the samples taken from the drillings executed in 2021, new laboratory investigations were performed in order to correctly identify the rocks in the slope structure (Table 1).

Table 1. Stratigraphy of the slope

\begin{tabular}{|l|l|l|l|}
\hline \multicolumn{2}{|c|}{ F1 Drilling } & \multicolumn{3}{c|}{ F3 Drilling } \\
\hline $0-0.20 \mathrm{~m}$ & Clay, carbonaceous clay & $0-1.80 \mathrm{~m}$ & Missing - unrecovered \\
\hline \multirow{2}{*}{$2.20-2.37 \mathrm{~m}$} & $\begin{array}{l}\text { Limestone marls with sandstone } \\
\text { appearance (fragmented) }\end{array}$ & $1.80-2.00 \mathrm{~m}$ & $\begin{array}{l}\text { Fragments of carbonaceous clay, } \\
\text { bituminous clay }\end{array}$ \\
\cline { 2 - 4 } $2.37-2.65 \mathrm{~m}$ & $\begin{array}{l}\text { Limestone marls (with limestone } \\
\text { fragments) }\end{array}$ & $2.00-2.30 \mathrm{~m}$ & Marl fragments, limestone marls \\
\cline { 2 - 4 } & $\begin{array}{l}\text { Limestone marls with sandstone } \\
\text { appearance (massive) }\end{array}$ & $5.00-5.00 \mathrm{~m}$ & $\begin{array}{l}\text { Limestone marls with sandstone } \\
\text { appearance }\end{array}$ \\
\hline RQD =80.55\% & $\begin{array}{l}\text { Limestone, limestone fragments, } \\
\text { dolomite limestone }\end{array}$ \\
\hline
\end{tabular}

The research team from the University of Petroșani (UP) came to the conclusion that the slope is made up of a succession of strata (having as reference the F1 drilling, considered to be, by positioning relative to the investigated area of the slope, representative) (Figure 5):

- at the top, a shallow layer of topsoil followed by a mixture of skeletal clays, sometimes with carbonaceous clays (difficult to separate, which is why subsequent investigations were carried out considering the whole mixture) (A layer);

- a layer of limestone marls with the aspect of sandstone, strongly cracked (fragmented) (M1 layer);

- a layer (intercalation) of limestone marl (I layer);

- a basic layer (relative to the depth of the geotechnical drilling) of massive limestone marls with the aspect of sandstone (not affected by cracks) (M2 layer).
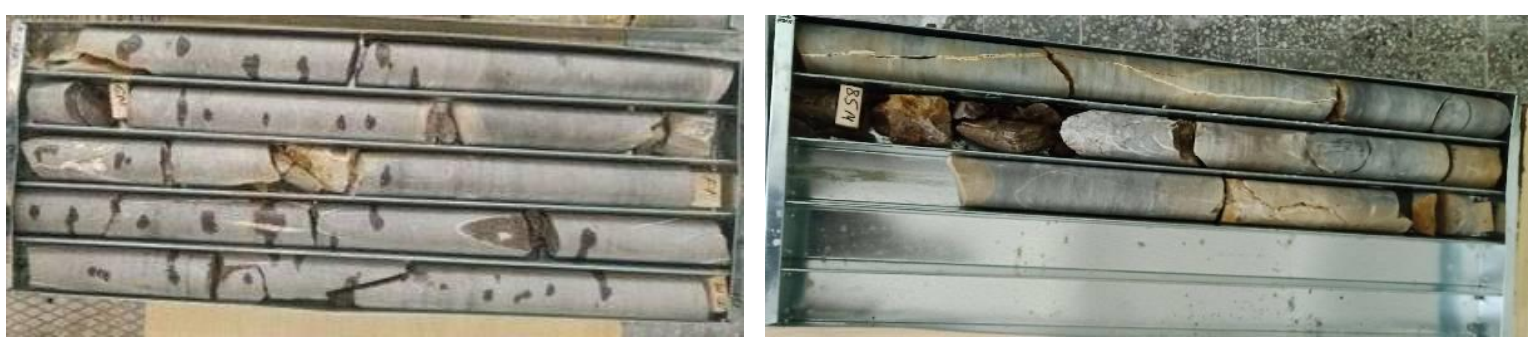

Figure 5. F1 and F3 drillings

From this point of view, the conclusions of the research team within UP are very close to those contained in the October 2015 study, noting that the I layer, that separates the two layers M1 and M2 (the strongly cracked and the massive one), is clearly highlighted.

What the three previous studies and the current one have in common is the fact that all of them (although they identify different types of rocks) highlight the high degree of fragmentation (cracking) of the M1 layer.

From a petrographic point of view, we are dealing with sedimentary rocks in transition between precipitation carbonate rock (myocritical limestone) mixed with clayey (siltic) terrigenous material [1].

The rocks in layers M1 and M2 are hard and compact (but cracked in the first layer and massive in the second). For the M1 layer, supergene and superficial alterations are observed. Also, in the composition of the analyzed samples were observed fine sequins of muscovite and diaclases with calcite (less than $5 \mathrm{~mm}$ thick) [1].

\subsection{Hydrology and climate}

Anina town is crossed by Gârliște river which is part of the larger Caraş river basin, being allocated to the area with rich humidity, namely to the group with strongly drained groundwater. 
Groundwater areas in crystalline rocks and intrusive rocks are distinguished by rich resources, located in the fissures of these rocks. In the upper deluvial layer, relatively large variations of the amounts of groundwater resources are characteristic, which is also reflected in the underground river supply regime, thus prolonging the period of high waters and the duration of floods [5].

Waters formed under such conditions are generally poorly mineralized (usually 50-200 mg/l) and belong to the carbonated water class. In depression areas or low terraces and meadows, the groundwater level can have relatively shallow depths, from $-1 \mathrm{~m}$ to $-10 \mathrm{~m}$.

From a meteorological point of view, the territory of Anina falls within the moderate continental climate sector, with the following characteristics $[1,5]$ :

- average annual temperature: $+10.5^{\circ} \mathrm{C}$;

- July average (warmest): $+21^{\circ} \mathrm{C}$;

- January average (coldest): $-0.8^{\circ} \mathrm{C}$;

- average amount of precipitation: $1200-1400 \mathrm{~mm} / \mathrm{year}$;

- frost depth: $100 \mathrm{~cm}$;

- number of days with frost: 106 days/year;

- average duration of the frost-free interval: 250 ;

- wind direction: E: $13.7 \%$; N: 12.4\%; NW: $11.5 \%,(62.4 \%$ calm).

\section{Slope stability investigations}

\subsection{Establishing the hypotheses of landslides occurrence}

After analyzing the structure of the investigated slope and based on the experience gained over the years by members of the research team, it was concluded that landslides can occur only at the contact surface between the constituent layers (these are usually areas of minimum strength, especially in the case of slopes made up of inclined strata, consequent with the slope of the terrain).

Thus, two generic surfaces on which the sliding surfaces can materialize were considered:

- the first (most likely and analyzed in detail) at the contact between layers A and M1 (the strongly fragmented one);

- the second (for which assessments were made on the basis of previous studies presented in the literature) at the contact between the I layer and the M1 layer.

\subsection{Physical and geomechanical characteristics of the rocks}

In order to perform stability analyzes, the next important step is to rigorously determine the physical and mechanical characteristics that characterize the rocks in the slope structure.

Thus, starting from the hypotheses of landslides occurrence considered in this study, determinations were made for each type of rocks encountered in drilling and for the contact surfaces between them (Figure 6), the results being presented in Tables $2-8$.
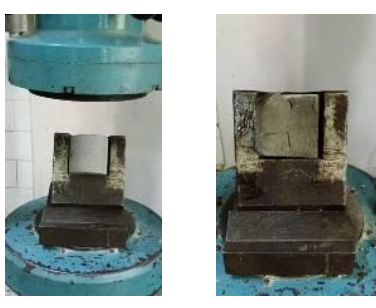

a

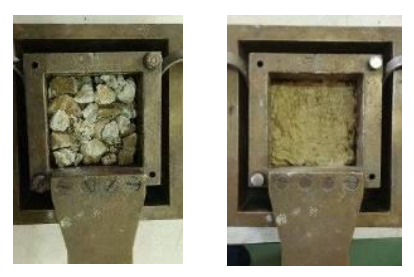

b
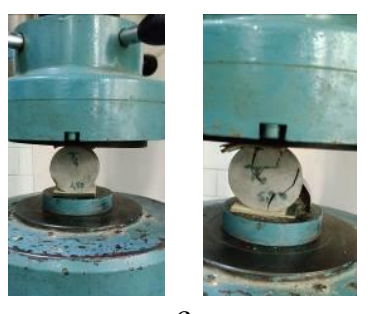

c
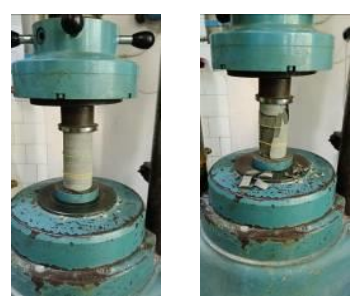

d

Figure 6. Determining the geomechanical characteristics: a - sheared specimens according to a mandatory plan;

b - limestone marls samples (inclusion) in the shear boxes (in natural and saturated state);

$\mathrm{c}$ - test specimens subjected to traction (Brazilian method); $\mathrm{d}$ - specimens subjected to uniaxial compression

Table 2. Physical characteristics of some rocks from the slope structure

\begin{tabular}{|c|l|c|}
\hline $\begin{array}{c}\text { Crt. } \\
\text { No. }\end{array}$ & Rock name/Collection place/State of the specimen & $\begin{array}{c}\text { Apparent density } \\
\text { (volumetric), } \mathbf{\rho a}\left[\mathbf{k g} / \mathbf{m}^{\mathbf{3}}\right]\end{array}$ \\
\hline 1. & Layer A/Superior strata/Natural moisture & 1.802 \\
\hline 2. & Layer A/ Superior strata /Saturation & 1.993 \\
\hline 3. & Layer I/Inclusion/Natural moisture & 2.341 \\
\hline 4. & Layer I/Inclusion/Saturation & 2.493 \\
\hline
\end{tabular}


Table 3. Apparent density (volumetric) of rocks from M1 and M2 layers

\begin{tabular}{|c|c|c|c|}
\hline \multirow{2}{*}{$\begin{array}{l}\text { Crt. } \\
\text { No. }\end{array}$} & \multirow{2}{*}{$\begin{array}{c}\text { Rock name/Collection place/State } \\
\text { of the specimen }\end{array}$} & \multicolumn{2}{|c|}{$\begin{array}{c}\text { Apparent density (volumetric), } \rho_{\mathrm{a}} \\
{\left[\mathrm{kg} / \mathrm{m}^{3}\right]}\end{array}$} \\
\hline & & On sample & Average \\
\hline 1. & \multirow{6}{*}{ Layer M1/Anina/Natural moisture } & 2.652 & \multirow{6}{*}{2.649} \\
\hline 2. & & 2.649 & \\
\hline 3. & & 2.645 & \\
\hline 4. & & 2.642 & \\
\hline 5. & & 2.649 & \\
\hline 6. & & 2.659 & \\
\hline
\end{tabular}

Table 4. Shearing resistance for specimens tested according to a mandatory plan (layer M1)

\begin{tabular}{|c|c|c|c|c|c|}
\hline \multirow{5}{*}{$\begin{array}{l}\text { Crt. } \\
\text { No. }\end{array}$} & \multirow{5}{*}{$\begin{array}{c}\text { Rock name/Collection } \\
\text { place/State of the specimen }\end{array}$} & \multicolumn{4}{|c|}{ Mechanical characteristic } \\
\hline & & \multicolumn{4}{|c|}{ Shearing resistance (mandatory plan) } \\
\hline & & \multicolumn{4}{|c|}{$\alpha=\mathbf{3 0}^{\circ}$} \\
\hline & & \multicolumn{2}{|c|}{$\sigma[\mathbf{M P a}]$} & \multicolumn{2}{|c|}{$\tau$ [MPa] } \\
\hline & & On sample & Average & On sample & Average \\
\hline 1. & \multirow{6}{*}{$\begin{array}{l}\text { Layer M1/Anina/ } \\
\text { Natural moisture }\end{array}$} & 16.96 & \multirow{6}{*}{16.94} & 9.79 & \multirow{6}{*}{9.78} \\
\hline 2. & & 16.30 & & 9.41 & \\
\hline 3. & & 17.54 & & 10.13 & \\
\hline 4. & & 17.77 & & 10.26 & \\
\hline 5. & & 15.77 & & 9.10 & \\
\hline 6. & & 17.32 & & 10.00 & \\
\hline
\end{tabular}

Table 5. Determining the cohesion and internal friction angle (layer M1) by shearing

\begin{tabular}{|c|c|c|c|c|c|c|c|}
\hline \multirow{5}{*}{$\begin{array}{l}\text { Crt. } \\
\text { No. }\end{array}$} & \multirow{5}{*}{$\begin{array}{c}\text { Rock } \\
\text { name/Collection } \\
\text { place/State of the } \\
\text { specimen }\end{array}$} & \multicolumn{4}{|c|}{ Mechanical characteristic } & \multirow{5}{*}{$\begin{array}{l}\text { Cohesion } \\
\mathrm{c}[\mathrm{MPa}]\end{array}$} & \multirow{5}{*}{$\begin{array}{c}\text { Internal } \\
\text { friction } \\
\text { angle } \\
\varphi\left[^{\circ}\right]\end{array}$} \\
\hline & & \multirow{2}{*}{\multicolumn{4}{|c|}{$\begin{array}{c}\text { Shearing resistance (mandatory plan) } \\
\qquad \alpha=60^{\circ}\end{array}$}} & & \\
\hline & & & & & & & \\
\hline & & \multicolumn{2}{|c|}{$\sigma[\mathrm{MPa}]$} & \multicolumn{2}{|c|}{$\tau$ [MPa] } & & \\
\hline & & On sample & Average & On sample & Average & & \\
\hline 1. & \multirow{6}{*}{$\begin{array}{l}\text { Layer M1/Anina/ } \\
\text { Natural moisture }\end{array}$} & 4.49 & \multirow{6}{*}{3.78} & 7.77 & \multirow{6}{*}{6.55} & \multirow{6}{*}{5.62} & \multirow{6}{*}{14.35} \\
\hline 2. & & 3.62 & & 6.28 & & & \\
\hline 3. & & 3.24 & & 5.62 & & & \\
\hline 4. & & 3.34 & & 5.79 & & & \\
\hline 5. & & 4.06 & & 7.03 & & & \\
\hline 6. & & 3.94 & & 6.82 & & & \\
\hline
\end{tabular}

Table 6. Determining the cohesion and internal friction angle (layer M1) by uniaxial compression and traction

\begin{tabular}{|c|c|c|c|c|c|c|c|}
\hline \multirow{3}{*}{$\begin{array}{l}\text { Crt. } \\
\text { No. }\end{array}$} & \multirow{3}{*}{$\begin{array}{c}\text { Rock } \\
\text { name/Collection } \\
\text { place/State of the } \\
\text { specimen }\end{array}$} & \multicolumn{6}{|c|}{ Mechanical characteristic } \\
\hline & & \multicolumn{2}{|c|}{$\begin{array}{l}\text { Resistance to uniaxial } \\
\text { compression, } \\
\text { бrc }[\mathrm{MPa}]\end{array}$} & \multicolumn{2}{|c|}{$\begin{array}{c}\text { Resistance to traction } \\
\text { (Brazilian method), } \\
\sigma_{\mathrm{rt}}[\mathrm{MPa}]\end{array}$} & \multirow[t]{2}{*}{$\begin{array}{c}\text { Cohesion } \\
\text { c [MPa] }\end{array}$} & \multirow{2}{*}{$\begin{array}{c}\text { Internal } \\
\text { friction } \\
\text { angle } \\
\varphi\left[{ }^{\circ}\right]\end{array}$} \\
\hline & & On sample & Average & On sample & Average & & \\
\hline 1. & \multirow{6}{*}{$\begin{array}{l}\text { Layer M1/Anina/ } \\
\text { Natural moisture }\end{array}$} & 27.14 & \multirow{6}{*}{28.38} & 10.36 & \multirow{6}{*}{10.12} & \multirow{6}{*}{8.47} & \multirow{6}{*}{28.31} \\
\hline 2. & & 29.14 & & 11.79 & & & \\
\hline 3. & & 28.67 & & 9.98 & & & \\
\hline 4. & & 29.59 & & 9.05 & & & \\
\hline 5. & & 28.19 & & 9.43 & & & \\
\hline 6. & & 27.56 & & 9.14 & & & \\
\hline
\end{tabular}

Table 7. Determining the cohesion and internal friction angle at the contact between layers I și M1

\begin{tabular}{|c|c|c|c|c|c|}
\hline \multirow{5}{*}{$\begin{array}{l}\text { Crt. } \\
\text { No. }\end{array}$} & \multirow{5}{*}{$\begin{array}{c}\text { Rock name/Collection } \\
\text { place/State of the } \\
\text { specimen }\end{array}$} & Mechanica & aracteristic & \multirow{5}{*}{$\begin{array}{c}\text { Cohesion } \\
\text { c }\left[\mathrm{daN} / \mathrm{cm}^{2}\right]\end{array}$} & \multirow{5}{*}{$\begin{array}{c}\text { Internal } \\
\text { friction angle } \\
\varphi\left[{ }^{\circ}\right]\end{array}$} \\
\hline & & \multirow{2}{*}{\multicolumn{2}{|c|}{$\begin{array}{c}\text { Shearing resistance (direct) } \\
\text { On the contact surface }\end{array}$}} & & \\
\hline & & & & & \\
\hline & & $\sigma\left[\mathrm{daN} / \mathrm{cm}^{2}\right]$ & $\tau\left[\mathrm{daN} / \mathrm{cm}^{2}\right]$ & & \\
\hline & & On sample & On sample & & \\
\hline 1. & \multirow{2}{*}{$\begin{array}{l}\text { I- M1/Anina/Natural } \\
\text { moisture }\end{array}$} & 1.75 & 4.86 & \multirow{2}{*}{2.72} & \multirow{2}{*}{31.84} \\
\hline 2. & & 2.25 & 5.28 & & \\
\hline 3. & \multirow{2}{*}{ I- M1/Anina/Saturated } & 1.75 & 2.36 & \multirow{2}{*}{0.91} & \multirow{2}{*}{27.47} \\
\hline 4. & & 2.25 & 2.71 & & \\
\hline
\end{tabular}


Table 8. Determining the cohesion and internal friction angle at the contact between layers A and M1

\begin{tabular}{|c|c|c|c|}
\hline $\begin{array}{c}\text { Crt. } \\
\text { No. }\end{array}$ & Rock name/Collection place/State of the specimen & $\begin{array}{c}\text { Cohesion } \\
\mathbf{c}\left[\mathbf{d a N} / \mathbf{c m}^{\mathbf{2}}\right]\end{array}$ & $\begin{array}{c}\text { Internal friction angle } \\
\boldsymbol{\varphi}\left[{ }^{\circ}\right]\end{array}$ \\
\hline 1. & A - M1/Anina/Natural moisture & 0.38 & 21.13 \\
\hline 2. & A - M1/Anina/Saturated & 0.23 & 19.02 \\
\hline
\end{tabular}

Analyzing tables 2 - 8, it can be see that, although the individual mechanical characteristics are some that could suggest that we are dealing with a more stable slope, if we focus on these characteristics in the case of contact surfaces between different layers of rocks, they are relatively low (especially at the contact of layers A and M1), and thus, under certain conditions, can lead to landslides that can involve significant volumes of rocks.

\subsection{Modeling the slope stratigraphy}

For modeling the slope stratigraphy, beyond the drilling performed in 2021, we took a series of information from previous geotechnical studies (especially geophysical investigations contained in the study conducted in May 2015 [3, 4] - Figure 7a), and for modeling the current geometry of the slope we considered the topographic profiles made in 2021.

Figure $7 \mathrm{~b}$ shows the geometry and stratigraphy of the slope, as modeled using the stability analysis software.

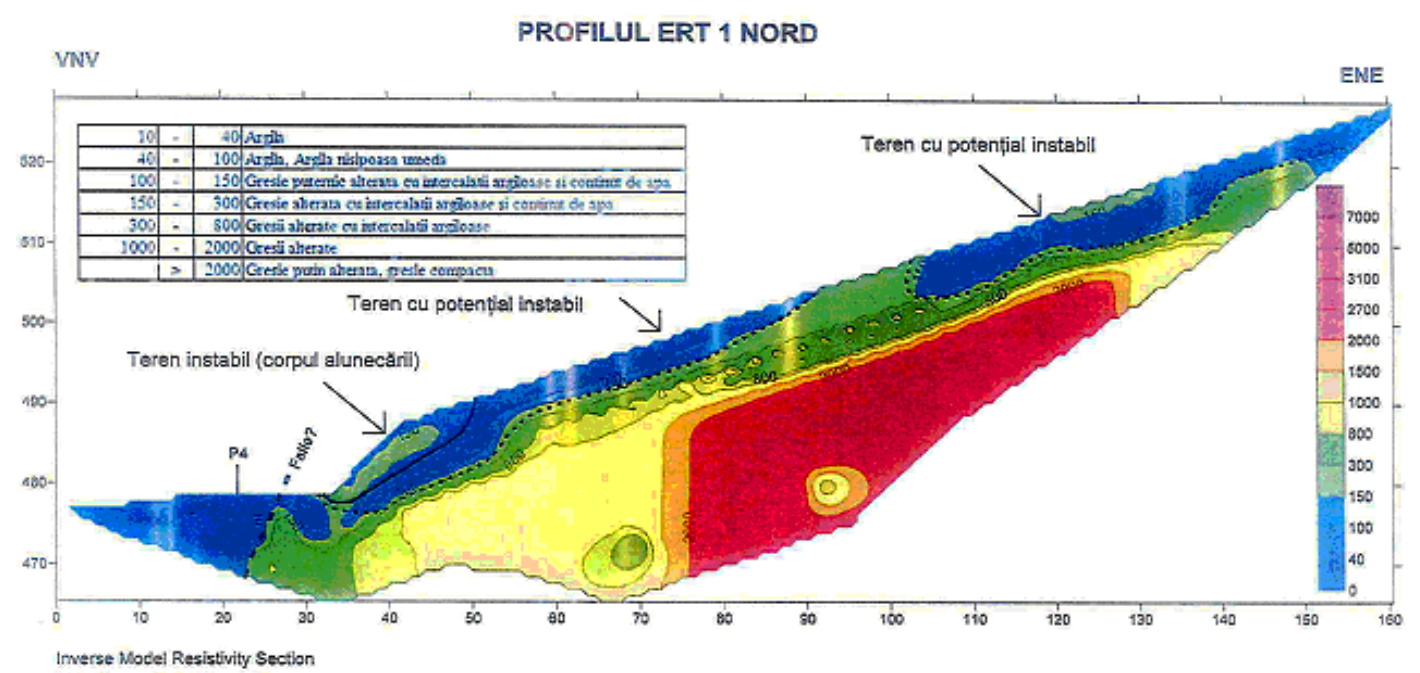
Irwerse Model Resistivity Sectlon
Unit electrode spacing $=3 \mathrm{~m}$

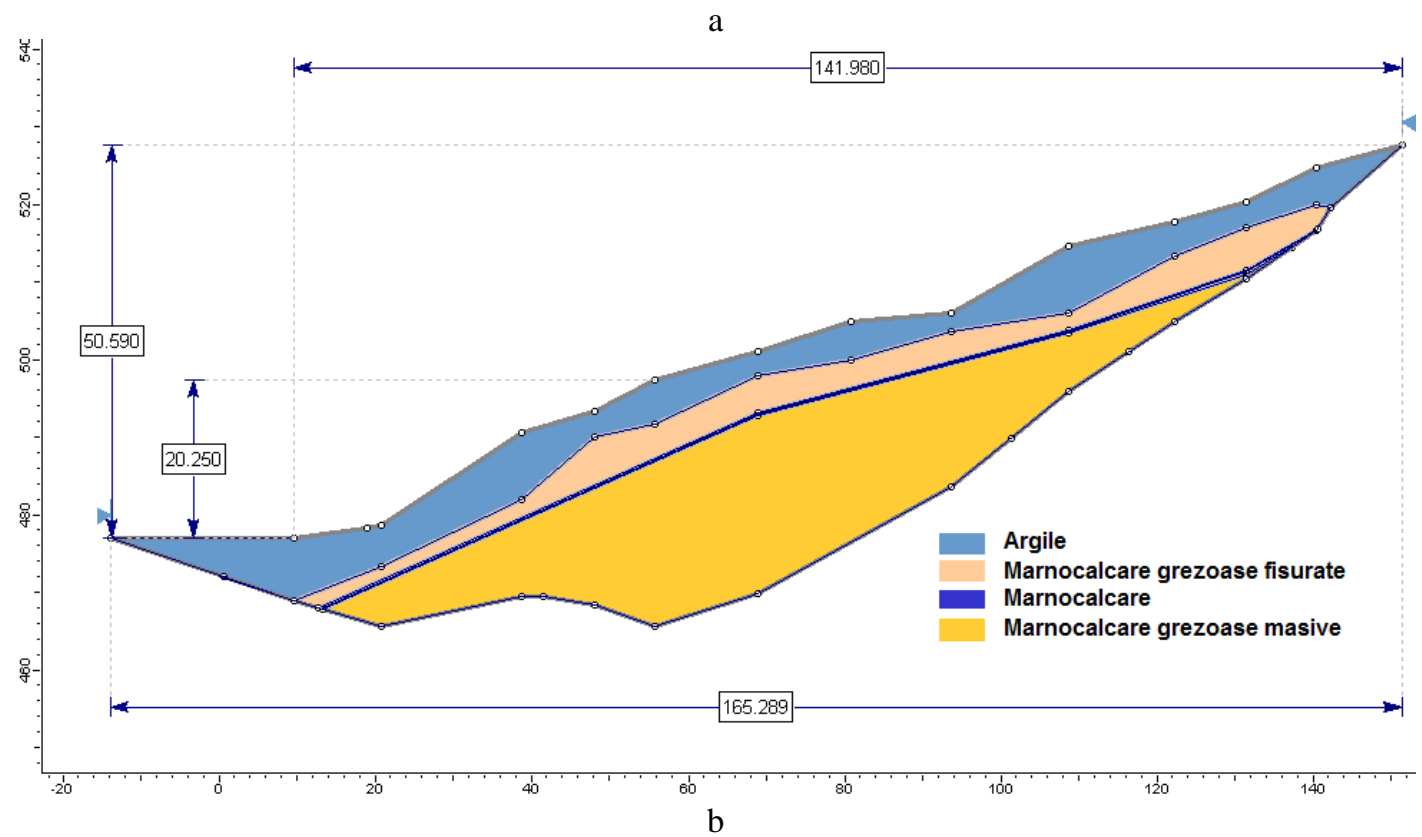

Figure 7 . The geometry and stratigraphy of the slope: a - geophysical profile [1,9]; b- model in Slide software 


\subsection{Performing stability analyzes}

Two specialized software (Slide and GeoTecB) were used to perform the actual stability analyzes, which allow the definition of generic sliding surfaces at the contact between the layers that make up the slope.

Hypothesis 1 - slide occurs at the contact surface between layers A and M1 (strongly fragmented).

The analyzes were performed taking into account, progressively, a series of factors that influence (negatively) the stability reserve of a slope (conditions of saturation of the constituent rocks and the hypothesis of earthquakes), so that some considerations can be performed on the appropriateness of resuming the excavations at the base of the slope to ensure the necessary space for the construction of premises A1, A2, A8 and A11 (according to the construction plan of WWTP Anina [2]).

The initial stability analyzes are presented in figure $8 \mathrm{a}-\mathrm{d}$ (performed with Slide software). We specify that the analyzes were performed by several procedures (Fellenius, Bishop, Janbu, Morgenstern-Price), well known and recommended by the literature $[6,7,8,9])$, in this paper being illustrated the situations for which the most unfavorable values were obtained (the lowest safety coefficients for each situation).
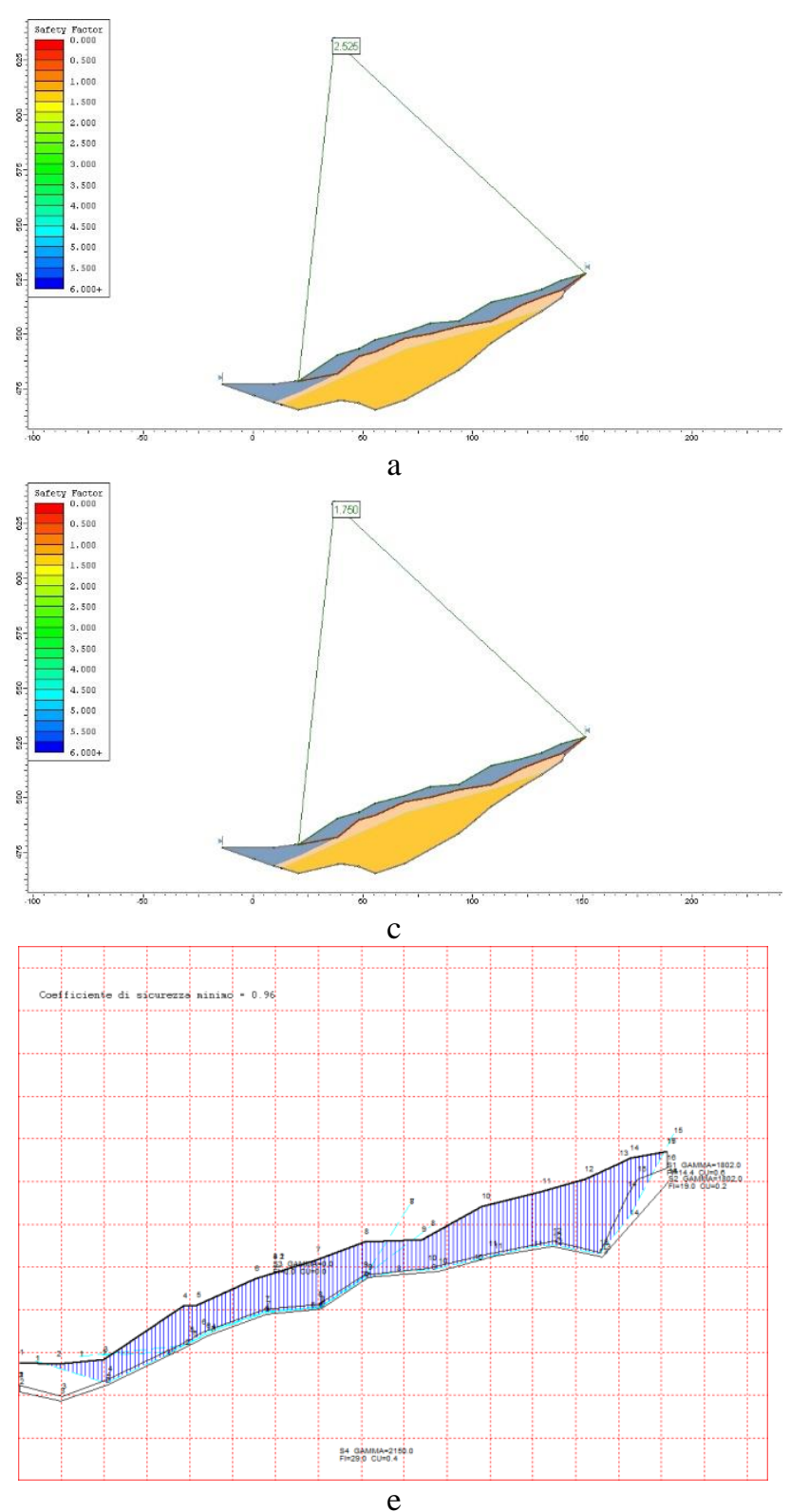
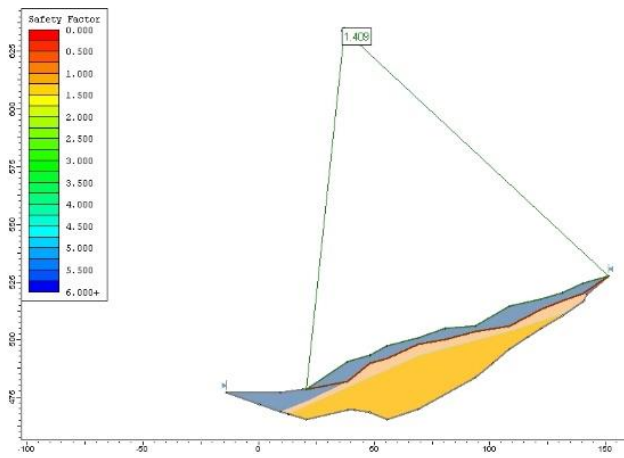

b
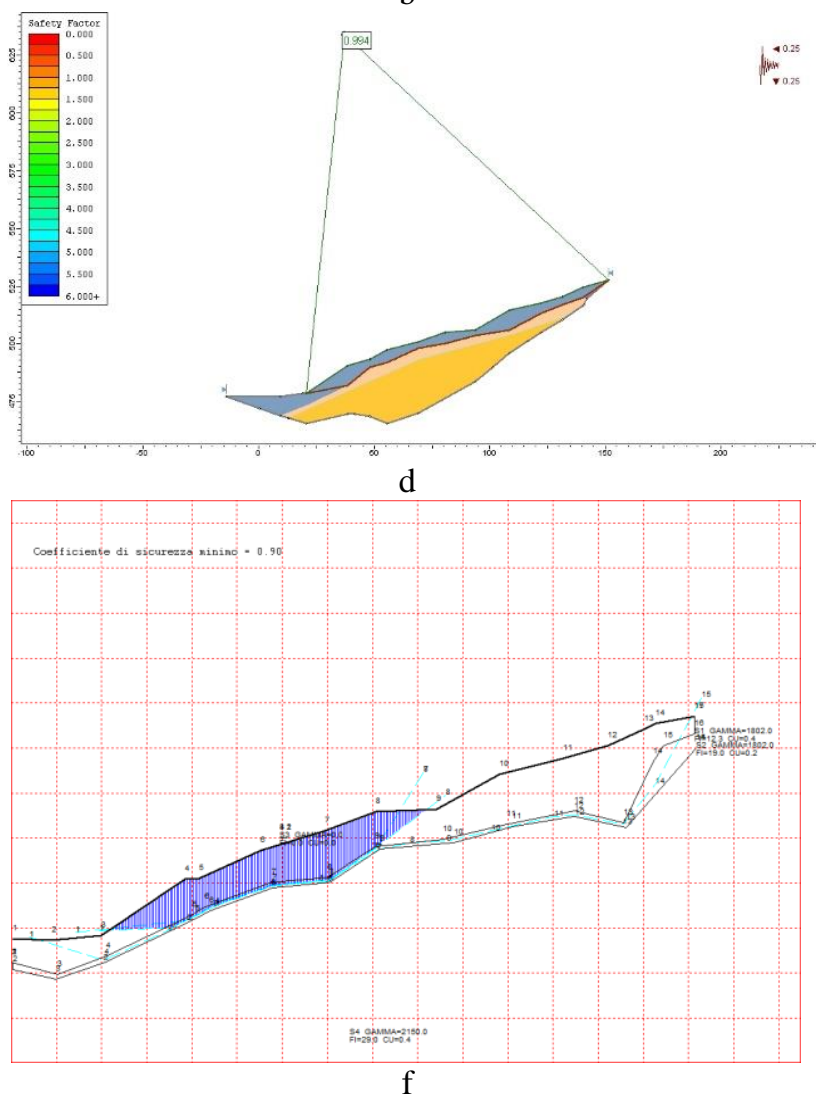

Figure 8. Stability analyzes: a - natural moisture of the contact area between the layers; $\mathrm{b}$ - natural moisture of the contact area between the layers considering the influence of a seismic shock with an acceleration of $0.25 \mathrm{~g} ; \mathrm{c}$ - saturation of the contact area between the layers; $d$ - saturation of the contact area between the layers and under the influence of a seismic shock with the acceleration of $0.25 \mathrm{~g}$; e - saturation of the contact area between the layers and under the influence of a seismic shock with the acceleration of $0.25 \mathrm{~g} ; \mathrm{f}$ - saturation of the contact area between the layers and of the upper clay layer and under the influence of a seismic shock with the acceleration of $0,25 \mathrm{~g}$ 
In order to validate the most unfavorable result, obtained taking into account the saturation of the contact area and the production of a seismic shock simultaneously with the development of excavation and/or construction activities on site, we doubled this analysis by using a second geotechnical software (GeoTecB) (Figure 8e).

A last analyzed situation considers not only the saturation of the contact area, but also of the clay layer located in the upper part of the slope. This possibility is shown in Figure 8f.

We also specify that in order to study the possible influence of seismic shocks on stability, in the analyzes we considered a seismic acceleration of $0.20 \mathrm{~g}$ (corresponding to the seismic zoning map of the Romanian territory contained in P 100-1 Design Code [10]), in which we added an acceleration of $0.05 \mathrm{~g}$, given by the vibrations transmitted by the machines to the slope in the hypothesis of resuming the excavation and construction activities.

In order to synthesize the results of the stability analyzes performed within the first hypothesis of producing a landslide, on a surface materialized at the contact between layers A and M1, we built table 9 .

Table 9. Results of the stability analyses

\begin{tabular}{|c|c|c|c|c|c|}
\hline $\begin{array}{l}\text { Crt. } \\
\text { No. }\end{array}$ & Sliding surface & Conditions and influence factors & $\begin{array}{c}\text { Analyses } \\
\text { method }\end{array}$ & $\begin{array}{c}\text { Safety } \\
\text { coefficient }\end{array}$ & Software \\
\hline 1. & \multirow{6}{*}{$\begin{array}{l}\text { Polygonal, at } \\
\text { the contact } \\
\text { between layers } \\
\text { A și M1 }\end{array}$} & Natural moisture & Janbu & 2.525 & Slide \\
\hline 2. & & Natural moisture + seismic shock & Janbu & 1.409 & Slide \\
\hline 3. & & Saturation & Janbu & 1.750 & Slide \\
\hline 4. & & Saturation + seismic shock & Janbu & 0.994 & Slide \\
\hline 5. & & Saturation + seismic shock & Fellenius & 0.960 & GeoTecB \\
\hline 6. & & $\begin{array}{c}\text { Saturation + saturated clays + seismic } \\
\text { shock }\end{array}$ & Fellenius & 0.900 & GeoTecB \\
\hline
\end{tabular}

Analyzing those presented in Figure 8 and Table 9 we can draw the following conclusions:

- in conditions of natural moisture (by which we mean the humidity at a given time of the rocks in the slope, in this case at the time of sampling, so variable, depending especially on the precipitation regime) the stability reserve is over 2.5. Such a stability reserve can be considered satisfactory, even in the analyzed case, and in accordance with the recommendations of the literature $[6,8,9]$;

- in conditions of natural moisture and under the influence of seismic shocks there is a reduction of approx. $44 \%$ of the stability reserve, down to a value of 1.409 ;

- in conditions of saturation of the contact area between the strata (situation that can materialize in conditions of moderate precipitation quantitatively and as intensity), the stability reserve of the slope is 1.750 ;

- although these values are supra-unitary, with stability reserves of $40.9 \%$ and $75 \%$ of the slope, they can be considered as insufficient for this case, close to important objectives and requiring the permanent presence of the staff (people) serving the premises (in this case WWTP Anina). For these situations it is recommended to adopt safety coefficients higher than 2.5 ;

- in conditions of saturation of the contact area between the layers and under the influence of seismic shocks, a reduction of approx. $43 \%$ of the stability reserve is observed (compared to the situation with saturated contact area), down to a value of 0.994 . This value, being sub-unitary, indicates to us that in such a situation it is very probable that a landslide will take place;

- after verifying this result, by using another geotechnical software, a value of the safety coefficient of 0.960 was obtained, ie close (the difference being less than $4 \%$ ), thus validating the initial result and confirming the high probability of landslide occurrence;

- for the last situation analyzed, ie in conditions of saturation of the contact area (occurs in case of heavy rainfall, high intensity) between layers and clays and under the influence of seismic shocks, we also find subunitary value of the safety factor (0.900), indicating again that there is a high probability of sliding. Another important aspect is related to the length on which the slide occurs. Thus in this situation, as we can see from figure $6 \mathrm{f}$, the length on which the sliding surface materializes is approximately $1 / 2$ of the total length of the potential surface at the contact between the layers. It may seem a more favorable situation, as it would apparently involve moving a smaller volume of material, but this is not the case at all. Thus, due to the radical change of the state of consistency of the clays (the passage, due to the high content of absorbed and adsorbed water, in a plastic state, which allows flowing) the slide will occur at a high speed, therefore the displaced material will travel a much greater distance, immediately endangering the objectives already built. Moreover, the upper part of the clays will move after this first phase because, they, also saturated in turn, would remain practically without support on a slope of about $30^{\circ}$. Therefore, in this situation we would face a complex with 
successive transmission or a regressive slide (depending on the moment when the clays at the top of the slope start moving, ie after a time measured in minutes or hours from the production of the initial slide or after seconds or fractions of a second), which would either lead to a further increase in the length of the sliding material or generate additional pushing forces (or a combination of the two effects) with serious consequences for the objectives in the area of influence (the already built buildings of WWTP Anina).

Hypothesis 2 - the sliding surface materializes at the contact between layers I (the intercalation between the layers M1 and M2, the fragmented upper one and the massive lower one) and M1 (Figure 9).

In this case, we must start the investigation from the fact that, as presented in this study, the M1 layer is strongly fragmented, which allows easy penetration of water to the layer I separating it from the lower layer M2, massive (characterized of a water absorption coefficient between 0.3 and $0.7 \%$, according to [1]).

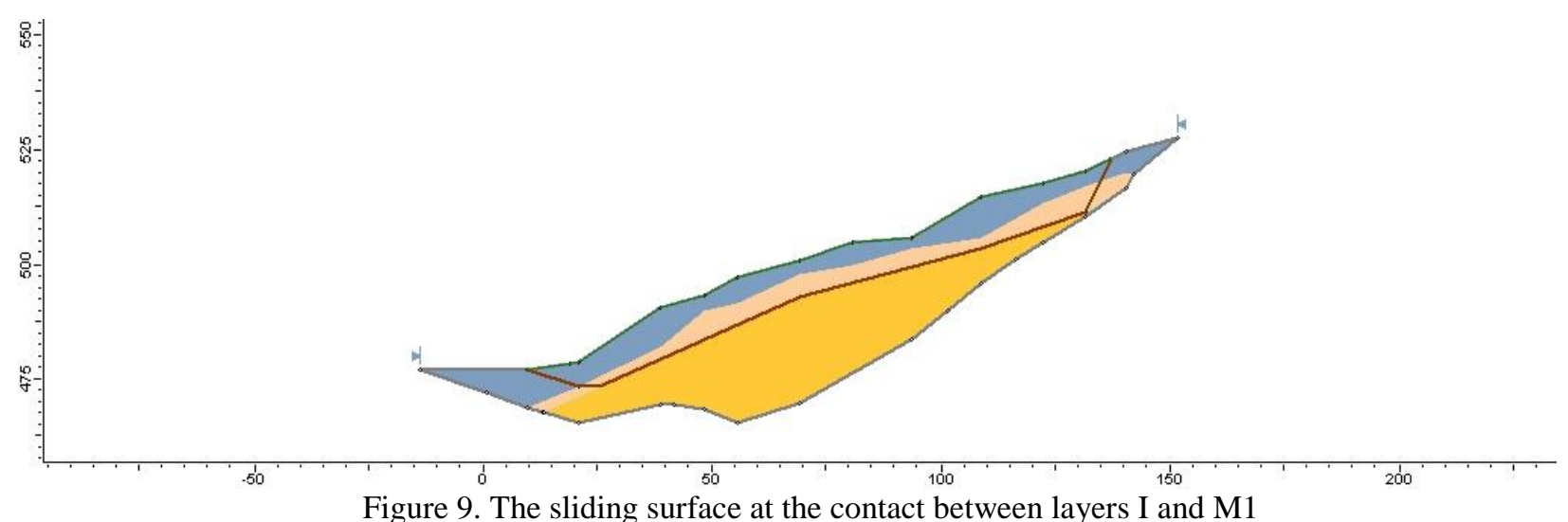

This situation creates favorable conditions for saturation of layer I, and after the maximum water absorption capacity is reached, it will be adsorbed, forming a film (pellicle) of the water between the layer I and the two layers M1 and M2. The appearance of such a water film would lead to a drastic reduction of the resistance characteristics on this contact area (practically the shear strength, expressed by cohesion and the internal friction angle would tend to 0 ).

Because the software used does not allow us to model the crack system affecting the M1 layer (nor do we have detailed information on this aspect) nor can we estimate a coefficient of structural weakening of the layer in question (determining with satisfactory accuracy requiring complex and long-term geological investigations), in order to present the possibility of a landslide through this area of the slope, the research team analyzed similar situations, encountered in previous studies or presented in the literature.

Therefore, in the case of the formation of a water film at the contact between layer I and M1 (situated above), against the background of the reduction towards 0 of the cohesion and the internal friction angle, there is a high possibility that the latter (layer M1) will enter a sliding motion, either of the entire layer or of large blocks (20 - $40 \mathrm{t}$ ), as probably happened in the case of the 2015 landslide.

The speed of movement, the distance at which the movement occurs, the volume of material entrained and implicitly the effects they can produce depend on a number of variables. As found in perhaps the most famous case of such slide (on a film of water formed at the contact between two rock layers), as of the right slope of the accumulation at Vajont (Italy), the speed was about $110 \mathrm{~km} / \mathrm{h}$ [11], but in the conditions of a slope with much higher inclination and height than in the analyzed case. The high speed with which such landslides occur translates into high energy and implicitly large-scale destructive effects.

The possibility of such a landslide must be considered especially in the event of a seismic shock (caused by natural causes, induced by human activities or a combination of the two), because, as we found in those presented in Hypothesis 1 of production of a landslide, it can reduce the stability reserve, whatever it is, by more than $40 \%$.

\section{Conclusions and recommendations}

Considering those presented in the paper we can draw the following conclusions:

1. There are significant differences in the way in which the rocks that make up the investigated slope were framed. The UP team, through the investigations carried out, came to conclusions, from this point of view, similar to the geotechnical study carried out in October 2015. 
2. Such discrepancies may also lead to erroneous modeling and misinterpretation of the technical condition of the massif (especially in the case of predictive analyzes), which in turn will lead to the design of incorrect technical stabilization solutions, and which will not produce the expected effects (thus endangering built objectives and even people's lives).

3. The stability analyzes performed showed that the slope has a satisfactory stability reserve (over 2.5) only in the most favorable situation analyzed, namely rocks at natural moisture and the absence of external influence factors. However, we point out that such a situation is too unrealistic, and cannot be considered as a benchmark in making a rational decision on the resumption of excavation work on the slope and the construction activities at its base.

4. For the rest of the analyzed situations, the safety coefficient presents either supra-unitary values, but below the value of 2.5 recommended by the specialized literature, or sub-unitary value, indicating an unstable slope.

5. We consider that at present the slope is in a relative state of equilibrium, but any intervention, in the sense of resuming the excavation activities in order to ensure the land area necessary for the construction of enclosures A1, A2, A8 and A11 (according to the construction plan of WWTP Anina [2]) could lead to the reactivation of the 2015 landslide, with its significant extension or to the onset of a new landslide, which materializes on a different slide plan than the original one or which differs by the production mechanism.

6. In these circumstances, the research team decided not to consider any execution of the remaining works related to the completion of the construction of WWTP Anina involving the resumption of excavations on the right side, and, implicitly, not to propose any constructive (technical) solution in this regard.

\section{Recommendations:}

1. In view of the results of the stability analyzes obtained for the most unfavorable situations, it is necessary to secure the slope in question immediately, and there is a real possibility of a landslide (or reactivation of the 2015 one) which would endanger objectives already built.

2. Given the short distance between the analyzed slope (relatively stable or unstable under certain conditions), the research team recommends the adoption of a higher safety coefficient than recommended by the literature, in this sense a value of at least 3 is suggested.

3. As such a value is difficult to obtain by simply reshaping the slope, the research team recommends reanalyzing the technical solution (through a specialized consulting company) with retaining wall (in both variants) proposed in the geotechnical study from May 2015. We specify that this technical solution aims only at securing the slope and in no case the resumption of excavations in this area.

Note:

When considering the adoption of a technical solution involving the construction of retaining walls, special attention should be given to changing the stress states in the massif (local stresses induced by the foundation and changing the overall stress state of the massif as a whole).

Moreover, the issue of tensions transmitted by the foundation to the massif (whether it is a dug or a drilled foundation) and changes in the global state of tension in the massif is treated on hundreds of pages in the literature $[9,12]$, and these aspects, taking into account the results regarding the slope stability reserve (especially in unfavorable situations), must be analyzed in detail before a decision is taken to build such structures (retaining walls), so that to involve minimal risks for the executors of the works and for the equipment involved in the process.

Another aspect that must be taken into account, in the case of adopting the solution with retaining walls, is related to the dynamic loads transmitted to the massif (in the form of vibrations) during the excavation/drilling of the foundation.

Dynamic, earthquake-induced loads were taken into account in the stability analyzes. These loads, however, act for short periods of time (maximum of the order of tens of seconds), as opposed to the dynamic loads induced during digging/drilling the foundation.

In the case of dynamic loads induced during the excavation/drilling of the foundation, even if they are lower than the seismic ones (in terms of intensity and acceleration, depending largely on the type of equipment used and the speed of execution of works), they are continuously manifested for much longer periods, and in this case there may be problems caused by the interaction (composition) of the waves transmitted to the slope (especially if digging/drilling is performed in several points simultaneously) and reflected from the slope, in terms of amplitude and frequency.

Therefore, this type of dynamic loads can be seen as possible triggers of a landslide, particularly dangerous, if we consider that it would occur during the execution of works, which involves the presence of people in the area of influence. 
4. Identification and delimitation of another perimeter (with an area of approximately $500 \mathrm{~m}^{2}$ ) necessary for the construction of premises A1, A2, A8 and A11 (according to the construction plan of WWTP Anina [2]) in a favorable area, which does not involve excavations in the area of the right slopes near WWTP Anina (on Gârliștei valley). In this regard, we recommend initiating a process to remove from the forestry fund an appropriate area of land (north, northeast of the existing buildings) and send this request to Romsilva (and possibly request the involvement of the local and county administration and decision factors in solving the problem).

\section{References}

[1] P.F.A. Pascalau Gigi, 2015

Geotechnical study for landslide investigation in the area of the Anina wastewater treatment plant, Carass-Severin county (in Romanian), Contract no. 458/2015, Bucharest

[2] ***, 2020

Situation plan, Wastewater Treatment Plant Anina (in Romanian)

[3] Corbescu G., 2016

Stabilization of the unstable slope at the Anina wastewater treatment plant (in Romanian), Revista Constructiilor (Constructions Revue), no. 127, pp. 32-33

[4] S.C. Expert S.R.L. Timișoara, 2015

Geotechnical expertise - Solutions for stabilizing the unstable slopes at the Anina wastewater treatment plant (in Romanian), Contract no. 3531/2015

[5] S.C. Geologic Don S.R.L. Ploiești, 2011

Geotechnical study for the realization of the project "Feasibility study and co-financing application for obtaining cohesion funds for Caraş Severin county for Anina locality" (in Romanian), Contract no. 135/2011

[6] Duncan C.W., Christopher W.M., 2005

Rock Slope Engineering. Civil and mining, 4th edition, Spon Press - Taylor \& Francis Group, 431 p., New York

[7] Lazăr M., Faur F., 2015

Stability and arrangement of slopes. Examples of calculation (in Romanian), Universitas P.H., 206 p., Petroșani

[8] Rotunjanu I., 2005

Stability of natural and artificial slopes (in Romanian), Infomin P.H., 351 p., Deva

[9] Stanciu A., Lungu I., 2006

Foundations. Earths physics and mechanics (in Romanian), Vol 1, Technical P.H., 1620 p., Bucharest

[10] Technical University of Civil Engineering Bucharest, 2013

Seismic design code P 100-1 (in Romanian), approved by MDRAP

[11] Petley D., 2008

The Vaiont (Vajont) landslide of 1963, The Landslide Blog, https://blogs.agu.org/landslideblog/2008/12/11/the-vaiontvajont-landslide-of-1963/

[12] Toderaș M., 2005

Geotechnics and foundations (in Romanian), Universitas P.H., 292 p., Petroșani 